\title{
DETERMINAN PEMBIAYAAN MUSYARAKAH PADA PERBANKAN SYARIAH DI INDONESIA
}

\author{
Teguh Permana ${ }^{1 *}$, Andriani Puspitaningsih ${ }^{2}$ \\ ${ }^{1}$ Jurusan IESP, Universitas Halu Oleo, Email: teguh.permana@uho.ac.id \\ 2 Jurusan IESP,Univeristas Halu Oleo, Email: andrianipuspitaningsih@uho.ac.id
}

\begin{abstract}
The results showed that third party funds, profit sharing rates, and problematic financing had a significant effect on musharaka financing, while inflation was not significant. Third party funds have a positive effect, while the profit sharing rate and problematic financing have a negative effect on musyarakah financing. Research also shows that there are different interceptions between BUS / UUS and BPRS where the BPRS intercept is greater than the BUS / UUS intercept. This shows that BPRS are more attractive to the public than BUS / UUS. The findings of this study imply that to increase the capacity of musharaka financing, efforts to increase community savings in third party funds are needed, promote a fair / appropriate profit sharing rate, and control problematic financing.
\end{abstract}

Keywords: musharaka, dpk, profit sharing, financing problems, inflation.

\begin{abstract}
ABSTRAK
Penelitian ini bertujuan untuk menganalisis determinan pembiayaan musyarakah di Indonesia. Jenis data adalah data sekunder dalam bentuk data bulanan yaitu sejak bulan Januari 2009 sampai bulan Desember 2017 yang bersumber dari Otoritas Jasa Keuangan (OJK) dan Badan Pusat Statistik (BPS). Metode yang digunakan adalah analisis regresi data panel dengan metode fixed effect model. Hasil penelitian menunjukkan bahwa dana pihak ketiga, tingkat bagi hasil, dan pembiayaan bermasalah berpengaruh signifikan terhadap pembiayaan musyarakah, sementara inflasi tidak signifikan. Dana pihak ketiga berpengaruh positif, sementara tingkat bagi hasil dan pembiayaan bermasalah berpengaruh negatif terhadap pembiayaan musyarakah. Penelitian juga menunjukkan bahwa terdapat intersep yang berbeda antara BUS/UUS dan BPRS dimana intersep BPRS lebih besar dari intersep BUS/UUS. Hal ini menunjukkan bahwa BPRS lebih diminati masyarakat dibanding BUS/UUS. Temuan penelitian mengimplikasikan bahwa untuk memperbesar kapasitas pembiayaan musyarakah, diperlukan upaya peningkatan saving masyarakat dalam dana pihak ketiga, mendorong tingkat bagi hasil yang adil/sesuai, dan upaya pengendalian pembiayaan bermasalah.
\end{abstract}

Kata kunci: musyarakah, dpk, bagi hasil, pembiayaan bermasalah, inflasi.

\footnotetext{
$1 *$ Penulis Korespondensi
} 


\section{PENDAHULUAN}

Masyarakat sudah mulai banyak yang percaya untuk menyimpan dananya di bank syariah yang dalam kegiatannya menggunakan sistem bagi hasil dan terhindar dari praktekpraktek riba yang biasa dilakukan di bank konvensional yang telah diharamkan dalam AlQur'an. Hal itu sesuai dengan firman Allah S.w.t dalam Al-Qur'an surat Ali 'Imran ayat 130 yang artinya: hai orang-orang yang beriman, janganlah kamu memakan riba dengan berlipat ganda dan bertakwalah kamu kepada Allah supaya kamu mendapat keberuntungan (Al-Qur'an Dan Terjemahannya, 1990:97).

\section{Tabel 1}

Laju Pertumbuhan Pembiayaan Musyarakah, Mudharabah Dan Murabahah Perbankan Syariah Di Indonesia Tahun 2009-2017

\begin{tabular}{|c|c|c|c|c|c|c|c|c|}
\hline \multirow[b]{2}{*}{ Tahun } & \multicolumn{2}{|c|}{ Pemb. Mudharabah } & \multicolumn{2}{|c|}{ Pemb. Musyarakah } & \multicolumn{2}{|c|}{ Pemb. Murabahah } & \multirow{2}{*}{$\begin{array}{c}\text { Selisih Pemb. } \\
\text { Musyarakah Pada } \\
\text { Pemb. Mudharabah }\end{array}$} & \multirow{2}{*}{$\begin{array}{c}\text { Selisih Pemb. } \\
\text { Musyarakah Pada } \\
\text { Pemb. Murabahah }\end{array}$} \\
\hline & $\begin{array}{c}\text { Nilai } \\
\text { (Miliar) }\end{array}$ & $\begin{array}{c}\text { Laju } \\
\text { Pert. } \\
(\%)\end{array}$ & $\begin{array}{c}\text { Nilai } \\
\text { (Miliar) }\end{array}$ & $\begin{array}{l}\text { Laju } \\
\text { Pert. } \\
(\%)\end{array}$ & $\begin{array}{c}\text { Nilai } \\
\text { (Miliar) }\end{array}$ & $\begin{array}{l}\text { Laju } \\
\text { Pert. } \\
(\%)\end{array}$ & & \\
\hline 009 & 0.556 & 0,30 & .649 & ,44 & 7.590 & 7,42 & 0,630 & 0,241 \\
\hline 010 & .696 & 17,62 & 4.841 & 23,21 & 9.129 & 1,82 & 1,707 & 0,379 \\
\hline 011 & 0.304 & 8,49 & 9.206 & 9,41 & 8.519 & 9,55 & 1,864 & 0,328 \\
\hline 012 & 2.122 & 7,64 & 7.988 & 5,73 & 0.858 & 5,26 & 2,309 & 0,308 \\
\hline 013 & 3.731 & 3,27 & 0.300 & 3,99 & 14.111 & 5,59 & 2,935 & 0,353 \\
\hline 014 & 4.476 & ,43 & 9.954 & 3,96 & 21.336 & ,33 & 3,451 & 0,412 \\
\hline 015 & 4.987 & ,53 & 1.365 & 2,84 & 26.602 & ,34 & 4,095 & 0,485 \\
\hline 016 & 5.448 & ,08 & 9.195 & 9,06 & 44.589 & 4,21 & 5,127 & 0,548 \\
\hline 017 & 7.214 & 1,43 & 02.281 & 9,15 & 56.236 & ,06 & 5,942 & 0,655 \\
\hline ata-rata & & 10,62 & & 9,31 & & 4,73 & & \\
\hline
\end{tabular}

Sumber: Data diolah, Otoritas Jasa Keuangan (OJK)

Dari Tabel $1 \mathrm{di}$ atas kita dapat melihat bahwa walaupun pembiayaan murabahah masih mendominasi pembiayaan syariah namun laju pertumbuhannya masih dibawah laju pertumbuhan pembiayaan musyarakah. Dengan rata-rata laju pertumbuhan pembiayaan musyarakah selama 9 tahun dari tahun 2009-2017 sebesar 39,3\%, bukan tidak mungkin pembiayaan musyarakah akan mendominasi pembiayaan di perbankan syariah. Menurut Ernawati (2016) bahwa pada satu sisi perbankan Islam lebih aman untuk mengalokasikan dananya pada kontrak musyarakah sebagai alternatif murabahah. Sedangkan menurut Ascarya 
(2015:214-215) bahwa pembiayaan musyarakah bisa memberi nilai tambah dan lebih superior dari pada pembiayaan mudharabah karena lebih bisa menghindari moral hazard sebab para pihak sama-sama menyertakan modal dan sama-sama memiliki suara dalam menentukan jalannya usaha.

Pemerintah Indonesia sekarang sedang berusaha membangun infrastruktur baik jalan maupun pusat-pusat pelayanan. Perbankan syariah bisa masuk di proyek-proyek pemerintah secara maksimal untuk membangun infrastruktur yang bisa memberi dampak efek multiplier yaitu terjadinya suatu kegiatan proyek infrastruktur maka akan memicu terjadinya kegiatan lain. Artinya ketika suatu proyek infrastruktur dibangun maka industri-industri dibawahnya akan bergerak untuk mendukung selesainya proyek tersebut dan itu akan menggerakkan ekonomi.

Bahkan bukan hanya efek multiplier yang bisa terjadi tetapi juga akan memberi dampak efek merembes kebawah atau lebih dikenal dengan istilah trickle down effect. Mengapa itu bisa terjadi, contohnya ketika perbankan syariah bekerja sama dengan kontraktor dengan mengeluarkan pembiayaan musyarakah untuk membangun pelabuhan di wilayah baru.

Kita tahu bahwa pelabuhan selalu menjadi titik awal pusat pertumbuhan suatu wilayah. Ketika pelabuhan itu selesai dan dipergunakan maka lama kelamaan wilayah itu pasti akan berkembang dan akan memberi dampak yang akan meluas di wilayah sekitarnya. Betapa besar dampak positif yang ditimbulkan jika perbankan syariah bisa fokus ke pembiayaan musyarakah daripada pembiayaan murabahah.

Sampai saat ini perbankan syariah di Indonesia masih di dominasi oleh pembiayaaan murabahah. Hal ini tidak hanya terjadi di Indonesia tetapi juga terjadi di Pakistan. Faroq dan Ahmed (2013) meneliti di Pakistan dengan fokus pada pembiayaan musyarakah karena di Pakistan juga ternyata pembiayaan murabahah yang dominan. Namun demikian pembiayaan musyarakah di Indonesia menunjukkan selisih yang terus menjauh dari pembiayaan mudharabah dan terus mendekat terhadap pembiayaan murabahah yang ditunjukkan pada tabel 1 .

Dari tabel 1 kita juga dapat melihat bahwa selisih pembiayaan musyarakah terhadap mudharabah sangat jauh perkembangannya yang pada tahun 2009 pembiayaan musyarakah lebih kecil 0,6 kali dari pembiayaan mudharabah dan pada tahun 2017 meningkat menjadi 5,9 atau 6 kali lipat dari pembiayaan mudharabah. Sedangkan untuk selisih pembiayaan 
musyarakah terhadap murabahah belum bisa sama dengan satu $(S=1)$ atau lebih dari satu $(\mathrm{S}>1)$ tetapi selisihnya terus mendekati satu. Artinya pelan tapi pasti pembiayaan musyarakah di masa mendatang akan mendominasi pembiayaan syariah. Jika dilihat dari trend selisih pembiayaan musyarakah terhadap murabahah selama 9 tahun naik 0,414 (0,655-0,241), berarti setiap tahun naik 0.045 maka butuh waktu kurang lebih 14 tahun agar pembiayaan musyarakah bisa sama atau lebih besar dari pembiayaan murabahah. Tentu waktu 14 tahun itu waktu yang cukup lama maka perlu diidentifikasi faktor yang mempengaruhi pembiayaan musyarakah agar bisa dilakukan strategi untuk meningkatkan perkembangan pembiayaan musyarakah lebih cepat.

\section{LITERATUR REVIEW}

Pembiayaan musyarakah adalah pembiayaan yang dilaksanakan berdasarkan akad syirkah yaitu kerja sama antara dua pihak atau lebih untuk membiayai suatu usaha atau proyek dimana masing-masing pihak memberi kontribusi baik modal uang maupun skill. Pembiayaan musyarakah dalam Islam dibolehkan dengan landasan syariahnya terdapat dalam surat AnNisa'a ayat 12 dan surat shaad ayat 24 .

Menghimpun dana pihak ketiga dibolehkan dalam Islam, hal ini sesuai dengan fatwa DSN MUI No.1 tentang giro, fatwa DSN MUI No.2 tentang tabungan, fatwa DSN MUI No.3 tentang deposito. Salah satu dalil yang dipakai ialah dalam Al-Qur'an Surat Al-Baqarah Ayat 283. Berdasarkan Undang-Undang Nomor 21 tahun 2008 tentang perbankan syariah Bab II Pasal 4 bahwa Bank Syariah dan UUS wajib menjalankan fungsi menghimpun dan menyalurkan dana masyarakat. Jadi bank syariah menghimpun dana dari masyarakat dalam bentuk dana pihak ketiga dan menyalurkannya kembali ke masyarakat dalam bentuk pembiayaan.

Sehingga dapat dikatakan bahwa semakin banyak dana yang dihimpun maka semakin besar pula dana yang bisa disalurkan, sehingga bisa disimpulkan bahwa semakin tinggi dana pihak ketiga maka pembiayaan juga cenderung semakin besar begitu pula sebaliknya. Menurut Nugroho (2009) bahwa dana pihak ketiga memiliki hubungan kointegrasi terhadap pembiayaan syariah. Sedangkan menurut Safitri (2016) bahwa dana pihak ketiga berpengaruh terhadap pembiayaan syariah. 
Tingkat bagi hasil yang dimaksud disini adalah porsi bagi hasil untuk pihak bank syariah. Berdasarkan hadits nomor 2487 dalam kitab Fathul Bari oleh AL-Asqalani bahwa Ibnu Baththal berkata: dari judul bab hadits no 2487 dapat disimpulkan bahwa dua orang yang berserikat ketika modal pokok mereka disatukan, maka keuntungannya dibagi antara mereka berdua (Al-Asqalani, 2015:202). Artinya bahwa berdasarkan hadits tersebut semakin mempertegas bahwa bagi hasil dibolehkan dalam Islam. Menurut Al Arif dan Euis (2010:205) bahwa dalam sistem bunga yang berubah adalah kurva TC (total cost) sedangkan dalam sistem bagi hasil yang berubah adalah kurva TR (total revenue). Dari sini kita dapat mengetahui bahwa tingkat bagi hasil akan mempengaruhi seberapa besar pendapatan yang bisa diperoleh. Jadi dapat dikatakan bahwa semakin tinggi tingkat bagi hasil pembiayaan maka semakin rendah pembiayaan karena pendapatan yang diperoleh juga cenderung rendah oleh pemohon, begitu pula sebaliknya semakin rendah tingkat bagi hasil pembiayaan maka semakin tinggi pembiayaan karena pendapatan yang diperoleh juga cenderung tinggi oleh pemohon. Menurut Ambarwati (2008) tingkat bagi hasil berpengaruh terhadap pembiayaan murabahah, sedangkan Haryadi (2009) menghasilkan hal berbeda yaitu ekuivalen rate pembiayaan tidak berpengaruh terhadap pembiayaan secara umum. Wahab (2014) juga sama menemukan hal yang sama pada pembiayaan mudharabah bahwa tingkat bagi hasil tidak berpengaruh terhadap pembiayaan mudharabah. Sedangkan Destiana (2016) belum memasukkan tingkat bagi hasil dalam penelitiannya pada pembiayaan musyarakah.

Pembiayaan bermasalah merupakan resiko buat perbankan yang mana resiko adalah sesuatu yang tidak pasti yang landasan syariahnya ada dalam surat Luqman ayat 34. Menurut Antonio dalam Destiana (2016) bahwa pembiayaan bermasalah (NPF) sangat berpengaruh terhadap pengendalian biaya dan sekaligus berpengaruh juga terhadap kebijakan pembiayaan yang akan dilakukan oleh bank. Semakin tinggi pembiayaan bermasalah (NPF) maka semakin kecil pembiayaan yang disalurkan. Pembiayaan bermasalah (NPF) yang rendah menyebabkan bank akan menaikan pembiayaan. Jadi bisa dikatakan bahwa semakin tinggi pembiayaan bermasalah (NPF) maka pembiayaan syariah cenderung akan semakin rendah begitu pula sebaliknya semakin rendah pembiayaan bermasalah (NPF) maka aka nada kecenderungan semakin tinggi pembiayaan syariah.

Menurut Ambarwati (2008) bahwa pembiayaan bermasalah berpengaruh signifikan terhadap pembiayaan murabahah sedangkan Haryadi (2009) juga menghasilkan hal yang sama bahwa 
pembiayaan bermasalah berpengaruh signifikan terhadap pembiayaan syariah secara umum. Namun berbeda dengan Wahab (2014) yang variabel net performing finance tidak berpengaruh signifikan terhadap pembiayaan mudharabah.

Al-Maqrizi (Karim, 2008:424-425) menyatakan bahwa peristiwa inflasi merupakan sebuah fenomena alam yang menimbulkan kehidupan masyarakat di seluruh dunia sejak masa dahulu hingga sekarang. Inflasi, menurutnya terjadi ketika harga-harga secara umum mengalami kenaikan dan berlangsung terus menerus, pada saat itu persediaan barang dan jasa mengalami kelangkaan dan konsumen karena sangat membutuhkannya, harus mengeluarkan lebih banyak uang untuk sejumlah barang dan jasa yang sama. Dari pendapat Al-Maqrizi ini bahwa akibat dari kenaikan harga maka masyarakat membutuhkan uang yang lebih besar. Juga menurut Irving Fisher (Darmawan, 1992:86) bahwa harga barang-barang yang menurun akan menghentikan atau mengurangi permintaan terhadap kredit sedangkan kenaikan harga barangbarang akan menambah permintaan terhadap kredit. Sehingga dapat dikatakan bahwa semakin tinggi inflasi maka pembiayaan juga akan semakin tinggi, sebaliknya jika inflasi rendah maka pembiayaan juga semakin rendah. Menurut Haryadi (2009) dalam penelitiannya menghasilkan bahwa inflasi tidak berpengaruh terhadap pembiayaan.

\section{METODE}

Jenis penelitian ini adalah penelitian eksplanasi yang bertujuan untuk melihat pengaruh antara variabel dana pihak ketiga, tingkat bagi hasil, pembiayaan bermasalah dan inflasi terhadap pembiayaan musyarakah pada perbankan syariah di Indonesia. Sumber data dalam penelitian ini berasal dari data sekunder yang bersumber dari Otoritas Jasa Keuangan (OJK) dan Badan Pusat Statistik (BPS) dalam bentuk data bulanan periode Januari 2009 sampai Desember 2017.

Analisis yang digunakan untuk menjawab rumusan masalah adalah regresi data panel yang di analisis dengan bantuan software EViews 10. Adapun modelnya sebagai berikut:

$$
\log (\mathrm{PMSY})_{\mathrm{it}}=\beta_{0}+\beta_{1} \log (\mathrm{DPK})_{\mathrm{it}}+\beta_{2} \mathrm{TBH}_{\mathrm{it}}+\beta_{3} \mathrm{~PB}_{\mathrm{it}}+\beta_{4} \mathrm{INF}_{\mathrm{it}}+\mathrm{e}_{\mathrm{it}}
$$

Kemudian dilakukan uji Chow untuk memilih model yang tepat digunakan. Setelah itu dilakukan uji ketergantungan Cross-Section dan uji multikolinieritas. Selanjutnya dilakukan uji hipotesis dan dibuat pembahasan atas hasil yang ditemukan. 


\section{HASIL DAN PEMBAHASAN}

Setelah melakukan serangkaian pengujian regresi data panel, penelitian ini menggunakan model Fixed Effect dengan White (Diagonal).

Hasil pengolahan data dengan menggunakan program EViews 10 sebagai berikut:

$\log \left(\mathrm{PMSY}_{\mathrm{it}}\right)=-4,6671+1,3507 \log \left(\mathrm{DPK}_{\mathrm{it}}\right)-0,0307 \mathrm{TBH}_{\mathrm{it}}-0,0271 \mathrm{~PB}_{\mathrm{it}}+0,0267 \mathrm{INF}_{\mathrm{it}}+\mathrm{e}_{\mathrm{it}}$

Dengan persamaan entitas sebagai berikut:

$$
\begin{gathered}
\log \left(\mathrm{PMSY}_{\text {BUS/UUS }}\right)=-5,2083+1,3507 \log \left(\mathrm{DPK}_{\mathrm{t}}\right)-0,0307 \mathrm{TBH}_{\mathrm{t}}-0,0271 \mathrm{~PB}_{\mathrm{t}}+0,0267 \mathrm{INF}_{\mathrm{t}}+\mathrm{e}_{\mathrm{t}} \\
\log \left(\mathrm{PMSY}_{\mathrm{BPRS}}\right)=-4,1259+1,3507 \log \left(\mathrm{DPK}_{\mathrm{t}}\right)-0,0307 \mathrm{TBH}_{\mathrm{t}}-0,0271 \mathrm{~PB}_{\mathrm{t}}+0,0267 \mathrm{INF}_{\mathrm{t}}+\mathrm{e}_{\mathrm{t}}
\end{gathered}
$$

Dari hasil uji $\mathrm{F}$ diperoleh hasil bahwa nilai probabilitas $\mathrm{F}(0,0000)<0,05$. Hal ini membuktikan bahwa secara simultan atau bersama-sama variabel bebas yaitu dana pihak ketiga (DPK), tingkat bagi hasil (TBH), pembiayaan bermasalah (PB), dan inflasi (INF) berpengaruh signifikan terhadap variabel terikat pembiayaan musyarakah (PMSY). Sehingga hipotesis 1 (H1) diterima. Kemudian dari tabel hasil regresi data panel juga diperoleh nilai adjusted $\mathrm{R}$ square sebesar 0,993. Hasil ini menunjukkan bahwa semua variabel bebas yaitu dana pihak ketiga (DPK), tingkat bagi hasil (TBH), pembiayaan bermasalah (PB), dan inflasi (INF) memiliki kontribusi sebesar 99,3 persen terhadap pembiayaan musyarakah (PMSY), sedangkan sisanya 0,7 persen dijelaskan oleh variabel lainnya yang tidak ada dalam penelitian ini.

Sedangkan dari uji t dihasilkan sebagai berikut:

\section{Dana pihak ketiga (DPK)}

Koefisien regresi dana pihak ketiga (DPK) bernilai 1,3507 dengan signifikansi 0,000. Hasil ini menunjukkan bahwa variabel dana pihak ketiga (DPK) berpengaruh signifikan terhadap pembiayaan musyarakah (PMSY) dengan arah positif. Hal ini ditunjukkan oleh nilai koefisien 1,3507 yang positif dan nilai probabilitas 0,000 lebih kecil dari nilai $\alpha(5 \%)$ atau 0,05 yang telah ditetapkan, sehingga $\mathbf{H 2}$ diterima.

2. Tingkat bagi hasil (TBH)

Koefisien regresi tingkat bagi hasil (TBH) bernilai $-0,0308$ dengan signifikansi 0,008. Hasil ini menunjukkan bahwa variabel tingkat bagi hasil (TBH) berpengaruh signifikan terhadap pembiayaan musyarakah (PMSY) dengan arah negatif. Hal ini ditunjukkan oleh nilai koefisien $-0,0308$ yang negatif dan nilai probabilitas 0,008 lebih kecil dari nilai $\alpha(5 \%)$ atau 0,05 yang telah ditetapkan, sehingga $\mathbf{H 3}$ diterima. 
3. Pembiayaan bermasalah (PB)

Koefisien regresi pembiayaan bermasalah (PB) bernilai -0,0271 dengan signifikansi 0,025. Hasil ini menunjukkan bahwa variabel pembiayaan bermasalah (PB) berpengaruh signifikan terhadap pembiayaan musyarakah (PMSY) dengan arah negatif. Hal ini ditunjukkan oleh nilai koefisien $-0,0271$ yang negatif dan nilai probabilitas 0,025 lebih kecil dari nilai $\alpha(5 \%)$ atau 0,05 yang telah ditetapkan, sehingga $\mathbf{H 4}$ diterima.

4. Inflasi (INF)

Koefisien regresi inflasi (INF) bernilai 0,0267 dengan signifikansi 0,185. Hasil ini menunjukkan bahwa variabel inflasi (INF) tidak berpengaruh signifikan terhadap pembiayaan musyarakah (PMSY) dengan arah positif. Hal ini ditunjukkan oleh nilai koefisien 0,0267 yang positif dan nilai probabilitas 0,185 lebih besar dari nilai $\alpha(5 \%)$ atau 0,05 yang telah ditetapkan, sehingga $\mathbf{H 5}$ ditolak.

Dari hasil penelitian juga ditemukan nilai intersep antara BUS/UUS dan BPRS berbeda dimana nilai intersep BPRS lebih besar dari pada nilai intersep BUS/UUS. Hal ini bisa terjadi karena laju pertumbuhan pembiayaan musyarakah pada BPRS lebih besar dari pada BUS/UUS. Hal tersebut menandakan bahwa BPRS lebih diminati masyarakat dari pada BUS/UUS dalam hal permintaan pembiayaan musyarakah.

\section{Pengaruh Dana Pihak Ketiga Terhadap Pembiayaan Musyarakah}

Hasil yang signifikan juga menandakan bahwa dana pihak ketiga berpengaruh terhadap pembiayaan musyarakah. Oleh karena itu semakin tinggi DPK maka akan mendorong alokasi pembiayaan musyarakah pada perbankan syariah, sebab DPK merupakan sumber utama pembiayaan bank. Temuan ini mengimplikasikan bahwa semakin tinggi tabungan (saving) yang dialokasikan masyarakat dalam bentuk DPK bagi bank, maka semakin mendorong alokasi pembiayaan di perbankan, yang pada akhirnya mendorong perekonomian, sehingga dana pihak ketiga menjadi faktor yang dapat dipertimbangkan untuk mempercepat peningkatan pembiayaan musyarakah.

Implikasi dari hal tersebut maka akan terjadi peningkatan pertumbuhan ekonomi. Hal itu bisa terjadi karena pembiayaan musyarakah diperuntukkan untuk sektor produktif yang bisa memberikan nilai tambah, bahkan multiplier effect dan trickle down effect. Contoh kasus 
dalam situs republika.co.id tanggal 6 Juli 2017 bahwa BNI Syariah dan PT. Brantas Abipraya melakukan penandatanganan akad plafond pembiayaan musyarakah. Akad plafond ini ditandatangani untuk memperkuat modal kerja untuk pengerjaan proyek-proyek sebesar $\mathrm{Rp}$ 200 miliar. BNI Syariah memberikan pembiayaan sebesar Rp 200 Miliar untuk keperluan modal kerja pengerjaan proyek seperti pengairan, bendungan atau waduk, pembangunan gedung, pembangunan jalan toll, pembangunan jembatan dan lain- lain. Dalam contoh kasus ini tentu akan menggerakkan roda perekonomian karena pengerjaan proyek tersebut membutuhkan tenaga kerja yang akan menyerap tenaga kerja sekaligus mengurangi pengangguran, menaikkan daya beli masyarakat yang pada akhirnya akan menggerakkan sektor konsumsi. Ketika itu terjadi maka roda perekonomian akan berputar dan kesejahteraan masyarakat akan meningkat.

Berdasarkan hal di atas maka untuk memperbesar kapasitas pembiayaan musyarakah, diperlukan upaya peningkatan saving masyarakat dalam dana pihak ketiga. Saat ini promosi penghimpunan dana pihak ketiga di public sudah mulai berkurang, sehingga perlu dijelaskan kembali kepada masyarakat bahwa bank syariah itu berbeda dengan bank konvensional. Karena sudah ada persepsi di masyarakat bahwa bank syariah dan bank konvensional sama saja, padahal kedua bank ini berbeda.

\section{Pengaruh Tingkat Bagi Hasil Terhadap Pembiayaan Musyarakah}

Tingkat bagi hasil bisa berpengaruh terhadap pembiayaan musyarakah karena semakin tinggi tingkat bagi hasil yang diterapkan bank syariah maka masyarakat cenderung tidak tertarik untuk mengambil pembiayaan. Artinya bahwa perbankan syariah harus menjaga tingkat bagi hasilnya agar masyarakat mau mengambil pembiayaan musyarakah. Dari hasil tersebut diatas mengindikasikan ternyata masyarakat memperhatikan tingkat bagi hasil dalam mengambil pembiayaan musyarakah.

Hasil yang signifikan juga menandakan bahwa tingkat bagi hasil berpengaruh terhadap pembiayaan musyarakah. Oleh karena itu semakin tinggi tingkat bagi hasil maka akan cenderung mengurangi pembiayaan musyarakah. Temuan ini mengimplikasikan bahwa peningkatan bagi hasil untuk perbankan akan menurunkan jumlah pembiayaan musyarakah, karena dari sisi permintaan, porsi bagi hasil untuk bank merupakan biaya bagi debitur. Hal ini mendorong debitur untuk menurunkan permintaan pembiayaan musyarakah. Sehingga 
tingkat bagi hasil pembiayaan musyarakah menjadi faktor yang dapat dipertimbangkan untuk mempercepat peningkatan pembiayaan musyarakah.

Kenaikan tingkat bagi hasil pembiayaan musyarakah cenderung akan mengurangi minat masyarakat maupun badan usaha untuk mengambil pembiayaan musyarakah karena tingkat bagi hasil yang tinggi akan mengurangi pendapatan yang akan dibagi ke bank syariah oleh masyarakat atau badan usaha. Namun ketika tingkat bagi hasil pembiayaan musyarakah yang rendah maka masyarakat atau badan usaha akan berani mengambil pembiayaan musyarakah karena pendapatan yang didapatkan lebih besar. Sebab saat ini revenue sharing yang dipakai pada perbankan syariah di Indonesia. Jika pembagiannya lebih besar untuk masyarakat atau badan usaha maka ada kemungkinan mendapatkan untung masih ada karena revenue sharing belum ketahuan apakah untung atau rugi karena belum dikurangi biaya. Sehingga ketika tingkat bagi hasil pembiayaan musyarakah naik maka cenderung akan mengurangi minat masyarakat atau badan usaha untuk mengambil pembiayaan musyarakah.

Implikasi dari hal di atas adalah ketika tingkat bagi hasil menurun maka masyarakat atau badan usaha cenderung akan mengambil pembiayaan musyarakah untuk kegiatan usaha mereka. Adanya suntikan dana dari pembiayaan musyarakah pada kegiatan usaha atau suatu proyek maka akan mengembangkan usaha tersebut atau melancarkan proyek tersebut. Berkembangnya suatu kegiatan usaha, tentu akan menggerakkan roda perekonomian karena akan merangsang kegiatan lain untuk beroperasi. Sebab suatu usaha tidak bisa berdiri sendiri dan jalan sendiri tetapi harus didukung oleh kegiatan lain dan ini yang disebut multiplier effect. Ketika suatu usaha berkembang atau proyek berjalan maka secara langsung akan menciptakan lapangan kerja yang diikuti berkurangnya pengangguran.

Contoh kasus dalam situs www.beritasatu.com bahwa PT Bank Syariah Mandiri (BSM) menandatangani perjanjian kerja sama fasilitas pembiayaan senilai 1 triliun rupiah pada PT Jasa Marga (Persero) Tbk sebagai modal kerja untuk pengembangan ruas jalan tol baru. Pembiayaan ini menggunakan akad Line Facility-Musyarakah (bagi hasil/syirkah) dengan tenor satu tahun. Tentu contoh kasus ini akan memberikan multiplier effect bahkan trickle down effect. Ketika pengembangan ruas tol baru yang dilakukan PT Jasa Marga (Persero), maka industri yang terkait dengan proyek tersebut akan semakin tumbuh. Di satu sisi PT Jasa Marga (Persero) sebagai BUMN akan memberikan pendapatan buat negara, juga 
industri-industri turunannya akan berkembang karena mendapatkan order, sementara itu daerah disekitar pembangunan proyek akan semakin berkembang dan akan tumbuh pusatpusat pertumbuhan baru sebagai akibat dari pembangunan proyek infrastruktur. Tetapi yang tidak kalah pentingnya perbankan syariah bisa lebih berkembang dan market sharenya akan cepat tumbuh sehingga kedepan dapat mengalahkan dominasi perbankan konvensional.

Berdasarkan hal di atas maka untuk memperbesar kapasitas pembiayaan musyarakah, diperlukan upaya untuk mendorong tingkat bagi hasil yang adil/sesuai. Agar masyarakat atau pelaku usaha dengan senang hati mengambil pembiayaan musyarakah pada perbankan syariah di Indonesia. Sehingga perbankan syariah bisa cepat tumbuh di tengah bayang-bayang bank konvensional yang mendominasi perbankan di Indonesia.

\section{Pengaruh Pembiayaan Bermasalah Terhadap Pembiayaan Musyarakah}

Hasil yang signifikan menandakan bahwa pembiayaan bermasalah berpengaruh terhadap pembiayaan musyarakah. Oleh karena itu semakin tinggi pembiayaan bermasalah maka akan cenderung mengurangi pembiayaan musyarakah. Temuan ini mengimplikasikan bahwa peningkatan pembiayaan bermasalah akan menurunkan alokasi pembiayaan musyarakah oleh perbankan, karena dari sisi penawaran pembiayaan bermasalah merupakan biaya yang harus ditanggung oleh bank sehingga menurunkan insentif perbankan untuk mengalokasikan dananya dalam bentuk pembiayaan musyarakah. Sehingga pembiayaan bermasalah menjadi faktor yang dapat dipertimbangkan untuk mempercepat peningkatan pembiayaan musyarakah.

Pembiayaan bermasalah sangat berpengaruh terhadap pembiayaan musyarakah karena jika pembiayaan bermasalah tinggi maka bank akan lebih selektif mengeluarkan pembiayaan musyarakah. Hal itu terjadi untuk menghindari terjadinya kerugian yang lebih besar, yang akan membuat Bank ditutup. Walaupun terkadang ketika NPF sudah mendekati bahkan melewati batas aman 5\%, OJK akan menghimbau para pemegang saham perbankan syariah untuk menyuntikkan modal ke dalam Bank untuk segera disalurkan ke pembiayaan agar NPFnya bisa turun. Tetapi hal itu hanya bersifat insidentil. Pembiayaan bermasalah (NPF) yang meningkat juga disebabkan oleh melemahnya sektor riil. Melemahnya sektor riil disebabkan oleh melemahnya daya beli masyarakat. Melemahnya daya beli masyarakat ditandai dengan penurunan penjualaan ritel, terutama disebabkan terbatasnya anggaran negara 
untuk pembangunan sektor riil. Padahal, pembangunan sektor riil berpotensi menghasilkan multiplier effect yang besar pada penciptaan lapangan kerja sehingga meningkatnya pendapatan masyarakat dan pada akhirnya mendongkrak daya beli. Akar permasalahan dari menurunnya daya beli masyarakat ini adalah minimnya dana APBN untuk pembangunan sektor riil. Hal itu terjadi karena pemangkasan anggaran pemerintah terus dilakukan sejak 2014. Akibat pemangkasan anggaran tersebut, roda perekonomian menjadi lambat.

Contoh kasus seperti yang dilansir keuangan.kontan.co.id bahwa PT Bank Syariah Mandiri (BSM) menandatangani perjanjian pembiayaan line facility untuk project financing atau modal kerja dengan plafon masing-masing Rp150 miliar untuk PT IMS, Rp160 miliar untuk PT IMST, dan Rp42 Miliar untuk PT IMSS. Adapun pembiayaan ini menggunakan akad musyarakah dengan tenor line facility 24 bulan. Ketiga perusahaan tersebut akan menggunakan dana modal kerja dari BSM untuk mengerjakan proyek-proyek yang diperoleh dari PT Inka (Persero). Seperti yang dikemukakan di pembahasan sebelumnya bahwa kegiatan seperti ini akan memberi dampak yang besar bagi perekonomian. Semua sektor akan bergerak karena proyek tersebut akan menggerakkan sektor ekonomi lain dan ujungnya akan membuat perekonomian tumbuh, yang pada akhirnya akan meningkatkan kesejahteraan masyarakat.

Berdasarkan hal diatas maka untuk memperbesar kapasitas pembiayaan musyarakah, diperlukan upaya untuk pengendalian pembiayaan bermasalah. Karena pembiayaan bermasalah adalah salah satu faktor utama yang membuat bank bisa ditutup yang akan merugikan para nasabah, dan jika banknya besar maka akan mengganggu stabilitas perekonomian.

\section{Pengaruh Inflasi Terhadap Pembiayaan Musyarakah}

Hasil penelitian ini sejalan dengan penelitian Haryadi (2009) bahwa inflasi tidak berpengaruh terhadap pembiayaan. Bedanya dengan penelitian ini adalah jika Haryadi (2009) mencoba di pembiayaan secara umum maka penelitian ini mencoba melihat secara spesifik pada pembiayaan musyarakah. Hasil penelitian ini juga sesuai dengan teori yang dikemukakan oleh Irving fisher bahwa ada kecenderungan ketika terjadi inflasi maka masyarakaat akan membutuhkan uang lebih untuk mendapatkan barang dan jasa. Sehingga ada kecenderungan masyarakat akan mencari tambahan uang untuk memenuhi kebutuhannya. 
Namun karena tidak signifikan maka inflasi bukan menjadi variabel yang berarti mempengaruhi pembiayaan musyarakah pada perbankan syariah di Indonesia.

Implikasi dari hal diatas bahwa semakin tinggi inflasi tidak menjamin terjadinya peningkatan pembiayaan musyarakah, sehingga inflasi bukanlah faktor yang dapat dipertimbangkan untuk mempercepat peningkatan pembiayaan musyarakah.

Inflasi tidak berpengaruh terhadap pembiayaan musyarakah karena dengan naiknya inflasi malah membuat masyarakat berpikir untuk mengambil pembiayaan. Masyarakat akan berpikir jika harga terus naik maka dalam pengembaliannya pasti kesulitan oleh karena dengan kenaikan harga akan menurunkan daya beli masyarakat atau nilai riil dari uang itu menurun. Hal tersebut bisa terjadi karena ketika terjadi inflasi, masyarakat cenderung menahan diri untuk belanja daripada harus meminjam uang. Kita tahu bahwa pembiayaan ini mengarah ke sektor produktif sehingga hal-hal yang terkait dengannya masih bisa ditunda. Lain halnya dengan kebutuhan primer yang sifatnya konsumtif, yang tidak bisa ditunda.

\section{KESIMPULAN}

1. Dana pihak ketiga, tingkat bagi hasil, pembiayaan bermasalah, dan inflasi berpengaruh signifikan secara bersama-sama terhadap pembiayaan musyarakah pada perbankan syariah di Indonesia. Artinya bahwa keempat variabel tersebut memiliki kontribusi terhadap naik turunnya pembiayaan musyarakah pada perbankan syariah di Indonesia.

2. Pembiayaan bermasalah berpengaruh negatif dan signifikan terhadap pembiayaan musyarakah pada perbankan syariah di Indonesia. Temuan ini mengimplikasikan bahwa peningkatan pembiayaan bermasalah akan menurunkan alokasi pembiayaan musyarakah oleh perbankan, karena dari sisi penawaran pembiayaan bermasalah merupakan biaya yang harus ditanggung oleh bank sehingga menurunkan insentif perbankan untuk mengalokasikan dananya dalam bentuk pembiayaan musyarakah.

3. Inflasi tidak signifikan mempengaruhi pembiayaan musyarakah pada perbankan syariah dengan arah positif. Dengan demikian, tingginya inflasi tidak menjamin terjadinya peningkatan pembiayaan musyarakah, sehingga inflasi bukanlah faktor yang dapat dipertimbangkan untuk mempercepat peningkatan pembiayaan musyarakah. 


\section{REFERENSI}

Al Arif, M Nur Rinto Dan Euis Amalia, 2010. Teori Mikro Ekonomi:Suatu Perbandingan Ekonomi Islam Dan Ekonomi Konvensional, Jakarta,Kencana.

Al-Asqalani, Ahmad bin ali bin hajar, 2015. Fathul Baari:Syarah Syahih Al-Bukhari Jilid 20, Abu hasan al-atsari (penerjemah), Jakarta, Pustaka Imam Asy-Syafi'i.

Al-Quran Dan Terjemahannya, 1990. Kerajaan Saudi Arabia:Mujamma’ Al Malik Fahd Li Thiba'at Al Mush-haf Asy-Syarif Medinah Munawwarah.

Ambarwati, S, 2008. Faktor-faktor yang mempengaruhi pembiayaan murabahah dan mudharabah pada bank umum syariah di Indonesia. Tesis, Program Studi Timur Tengah Dan Islam Pascasarjana Universitas Indonesia, Jakarta.

Ascarya, 2015. Akad Dan Produk Bank Syariah, Jakarta, Rajawali Pers.

Darmawan, Indra, 1992. Pengantar Uang Dan Perbankan, Jakarta, PT Rineka Cipta.

Destiana, R, 2016. Analisis Dana Pihak Ketiga dan Risiko Terhadap Pembiayaan Mudharabah dan Musyarakah Pada Bank Syariah di Indonesia. LOGIKA, 17(2), 42-54.

Ernawati, 2016. Risk of Profit Loss Sharing Financing: The Case of Indonesia. Al-Iqtishad: Jurnal Ilmu Ekonomi Syariah, 8(1), 101-116.

Farooq, M., \& Ahmed, M. M. M, (2013). Musharakah financing: Experience of Pakistani banks, World Applied Sciences Journal, 21(2), 181-189.

Haryadi, 2009. Analisis Faktor-Faktor Yang Mempengaruhi Penyaluran Pembiayaan Pada Perbankan Syariah Di Indonesia. Tesis, Program Pascasarjana Kajian Timur Tengah Dan Islam Universitas Indonesia, Jakarta.

Http://www.beritasatu.com/bank-dan-pembiayaan/436104-bsm-salurkan-pembiayaan-rp-1triliun-ke-jasa-marga.html, diakses 27 April 2018

Https://www.ojk.go.id , data publikasi statistik perbankan syariah, diakses 26 Maret 2017

Https://www.bps.go.id, data inflasi Indonesia bulanan, diakses 26 Maret 2017.

Https://keuangan.kontan.co.id/news/bsm-teken-akad-pembiayaan-dengan-grup-pt-inka diakses 27 April 2018

Https://www.republika.co.id/berita/ekonomi/syariah-ekonomi/17/07/06/osnstw36 8-bnisyariah-salurkan-pembiayaan-kepada-brantas-abipraya, diakses 27 April 2018 
Karim, Adiwarman, 2008. Sejarah Pemikiran Ekonomi Islam, Jakarta, PT Raja Grafindo Persada.

Nugroho, Ris Yuwono Yudo, 2009. Analisis Faktor-Faktor Penentu Pembiayaan Perbankan Syariah Di Indonesia : Aplikasi Model Vector Error Correction. Tesis, Program Studi Ilmu Ekonomi Pertanian Sekolah Pascasarjana Insitut Pertanian Bogor, Bogor.

Safitri, I., Nadirsyah, N., \& Darwanis D, 2016. Pengaruh Kinerja Keuangan Terhadap Pembiayaan Bank Umum Syariah Di Indonesia (Periode 2009-2013), Share Journal of Islamic Economics and Finance, Vol. 5 No. 2 p. 155-164.

Undang-Undang Republik Indonesia Nomor 21 Tahun 2008 Tentang Perbankan Syariah.

Wahab, 2014. Analisis Pengaruh FDR, NPF, Tingkat Bagi Hasil, Kualitas Jasa Dan Atribut Produk Islam Terhadap Tingkat Pembiayaan Mudharabah Pada Bank Umum Syari’ah Di Semarang. Economica, Jurnal Ekonomi Islam, Vol. 5 No. 2 p. 107-136. 